\title{
María Dhialma Tiberti, promesa para la Argentina
}

F sta jovencita llega a la poesía con un caudal lírico ultramodernista heredado en temprana edad. Es autora ya, a los veintitrés años, de tres libros de versos, Cielo recto. (1947), Tierra de amapolas (1948) y Las sombras amarillas (1950), y de cinco comedias infantiles recogidas bajo el título de Los títeres (1948).

En Cielo recto, su joven espíritu entregado al ritmo interior de los asombros de adolescente, se expresa en la melodía de la imagen que encuentra en el verso libre la forma propicia. La gran poetisa argentina María de Villarino, que tan jerárquica se muestra en sus comentarios sobre obras literarias, dice de este primer libro:

La poesía de María Dhialma Tiberti es un claro y hondo paisaje de adolescencia como ella misma: honda para captar la belleza sensible; clara para expresar sus intuiciones. En la forma libre y desceñida de su verso, logra el dominio de la idea poética, de la que brota, naturalmente, su palabra, iluminando todo lo que nombra. Pura y fresca, su emoción vibra en sonidos esenciales por jardines de sueños...

Llevada de la mano por su magnífica adolescencia, María Dhialma Tiberti penetra en el ámbito de la poesía por un camino de luz. ${ }^{1}$

Desde los primeros poemas se siente en seguida la fuerte personalidad de esta escritora, casi niña, atenta a los sonidos y ritmos de la poesía no sólo de hoy sino también de ayer, que no desprecia nada y que no imita servilmente tampoco, pues en su temperamento se resuelven las diversas influencias que la guían logrando unidad de tono y sinceridad poética al hablar en imágenes sencillas y plás- 
ticas, de la melancolía indefinida y confusa de la juventud. Todo ese sentir impreciso y desconocido que emociona sus pocos años lo devuelve con asombrosa fidelidad. En la poesía que abre el volumen, titulada sencillamente "De mí misma", nos habla de su emoción al soñar que era un lago tranquilo:

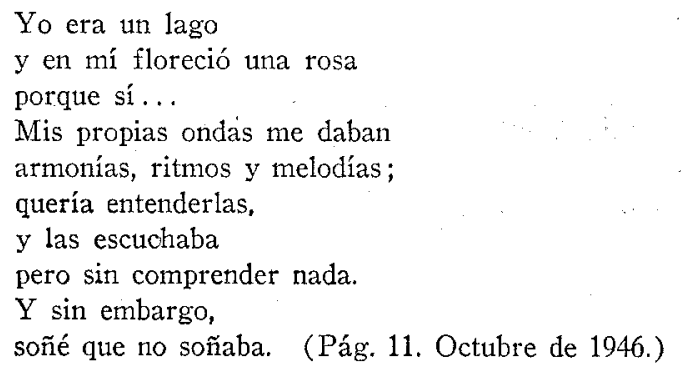

Algo de Antonio Machado y de Juan Ramón Jiménez se encuentra en éstos y a lo largo de muchos versos de María Dhialma, más patentemente quizás en "Copla" o en "Jardín". ${ }^{2}$ María Dhialma ha leído y asimilado la poesía de Juan Ramón Jiménez, Pablo Neruda, Amado Nervo, Alfonsina Storni, Jorge Luis Borges y de poetas más recientes, hasta de su misma generación. ${ }^{3}$ Sencilla y sin pretensiones admite su predilección por Juan Ramón Jiménez y el primer Pablo Neruda de los Veinte poemas de amor y una canción desesperada, así como la poca atracción que ejerce sobre ella el romanticismo. $\mathrm{Y}$ es verdad que su poesía, íntima y personal, no tiene del romanticismo sino lo más fino y delicado, lo más tenue y sutil, lo que de él ha sobrevivido en el modernismo. Por eso, quizás más que a Campoamor prefiere a Bécquer, y aún parece que más que de Bécquer tiene de él lo que ha recogido Juan Ramón Jiménez en sus Rimas de sombrá y en sus Arias tristes.

Silvina Bullrich, que leyó y gustó de Cielo recto, veía sin embargo en él "cierto hermetismo proveniente de la falta de confesiones íntimas y también de la falta de rima cuya cadencia ayuda a la comprensión". " Esta última aserción es cierta, en general, para toda la poesía; pero la impresión que nos produce a nosotros la poesía de María Dhialma es más bien la de una simplicidad y facilidad comunicativa muy lejos de hermética, porque la emoción de su poesía es instantánea en el lector, y la espontaneidad, la ingenuidad 
con que se dicen las cosas son más comunicativas que el contenido mismo del poema. Se nos hace fácil captar esas asociaciones que caen fuera del lugar común y que nos sugieren estados de ánimo inexplicables en su complejidad pero que reconocemos en nosotros mismos.

- Entre las poesías de Cielo recto se destacan "Llamada", "Versos", "Partida", "Preludio" y "Poema sencillo". .

Las imperfecciones, naturales en todo libro primero, son menos frecuentes en Tierra de amapolas, volumen sobre el cual poetas de indiscutible valor han reconocido al joven poeta que hay en María Dhialma. Entre ellos quisiéramos citar las palabras de María Alicia Dominguez :

En Tierra de amapolas María Dhialma se revela poeta singular, fiel a su ámbito y a su tiempo. En ella la imagen precede directamente de la emoción: "yo inventé el tiempo para decir tu nombre" y el universo se ofrece nuevo a sus ojos asombrados, capaces de apreciar el matiz, lo mismo que el color. Estas amapolas de su tierra amanecida, participan del fuego de la juventud y tienen la experiencia de la sangre. Porque su verso juvenil confiesa la eterna inquietud de la vida, el dolor de lo irremediable y la instintiva sabiduría de la experiencia, que anticipa sus frutos en la obra de los poetas natos. Por eso, ella puede cantar algo tan bello y tan profundo como "Tú y yo", 6

El poema a que se refiere María Alicia es obra de la intuición, y por ello no necesita la autora de aprendizaje para dar los sonidos más puros con sencilla pero segura maestría:

Tú y yo. Sombras.

Somos sólo sombras presas en un acuario celeste.

Tú, inventas las huídas.

Yo, me resigno a los regresos.

Ambos deshilamos los días,

tejemos los encuentros,

decimos los adicses con palabras

frías de nostalgia.

Tú y yo. Voces.

Somos sólo voces cautivas de un tiempo y de una tarde.

Tú, alejas las frases.

Yo, acerco las miradas. 
Ambos cruzamos las sontisas, con equívoco brillo de inexacta espada. Tú y yo. Quejas.

Somos sólo quejas anudadas a un lejano llanto.

$T u ́$, olvidas las presencias.

Yo, recuerdo las distancias.

Ambos volvemos insensiblemente

a oscuros recodos

con sabor de lágrimas.

Tú y yo. Esperanzas.

Somos sólo esperanzas

dispersas en un viento iluminado.

Tú, gritando lo pasajero.

$Y_{O}$, callando lo definitivo.

Ambos fingiendo partidas

por azules e insospechadas,

irreales galerías.

Tú y yo. Mentiras.

Somos sólo mentiras

atadas a crueles hojas de sable.

Tú, engañas a mis ojos.

Yo, miento a tus palabras.

Ambos creemos hilvanar historias con tiernas llegadas.

i Absurdos versos con perfil romántico!

Tú y yo. Nada. 7

No es este el único poema que nos parece logrado. Su segundo libro se destaca por la sostenida calidad poética, a pesar de revelar concretas o lejanas influencias de los poetas que mencionábamos antes y quizás de algunos más. La prueba de que hay varias excelentes composiciones en él es que quienes lo han leído han destacado, como los más hermosos, diferentes poemas. Raúl Amaral, por ejemplo, menciona como mejores "Forastera de tu tiempo", "Día final", "Canto de espera, desesperado", "Lejano pescador de lágrimas". "No sé cómo he llegado", 8 mientras que María Alicia Domínguez destaca "Soy", "Tú y yo".

Tierra de amapolas habla de estados íntimos, de asombrados desencantos, de ardorosas anticipaciones, del mundo de los sentimientos vagos y poderosos a un tiempo de la adolescencia; pero siempre con medida y reserva, y sin otro hermetismo que el del alma 
humana, sin otra oscuridad que la del sentir profundo. Raúl Amaral piensa en Jorge Guillén, en Pedro Salinas, en Julio J. Casal, al detenerse en los poemas de María Dhialma. Nosotros pensamos, guardando distancias, en Pablo Neruda, en Rafael Alberti, en Juan Ramón Jiménez, y alguna vez en la lejana, sencilla y nostálgica "canción de amigo" en la que algunos poetas de los últimos años se han inspirado. Así dice en "Canto de espera, desesperado":

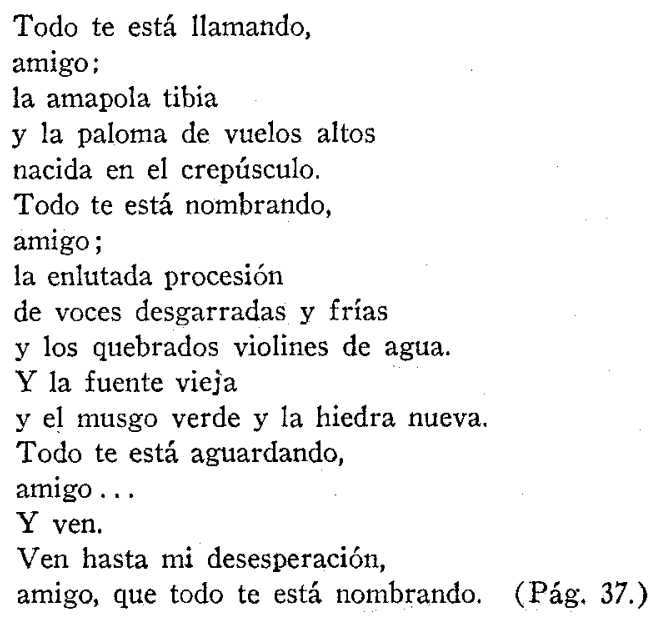

Deliciosamente ingenua, María Dhialma puede sentirse dueña de la vida en un poema lleno de esperanza y de juventud:

Yo inventé el tiempo
para decir tu nombre.
Porque mi voz lo quiso,
hubo violetas en verano
y glicinas en otoño. (Pág. 5.)

Y también ha encontrado una manera plástica, exacta de describir los indecisos temores, siempre vencidos, de la adolescencia: 
a la temprana partida

sólo por ver si hay un reflejo

que pueda salvarse. (Pág. 47.)

El poeta y director de la revista Alfar de Montevideo, Julio J. Casal, ve en ella un valor seguro y dice así lo que significa para él esta poetisa:

En usted encontramos un dejarse ir por las cosas, casi sin tocarlas, desnudándose en ellas, hasta desaparecer usted, dejándonos solamente las cosas y un recuerdo de su paso por ellas. ${ }^{9}$

Horacio Rega Molina ve en este libro "esencia de mito poético en sus imágenes... la presencia de un espiritu que se amplia en perspectivas subjetivas de apasionada hondura poética..." 10

Las sombras amarillas continúa y supera, en muchos aspectos, la inspiración de Tierra de amapolas. Hay en él nostalgias y recuerdos dentro de una mayor conciencia artística que por momentos reemplaza la intuición que guiaba los dos primeros libros. Nada que lo demerite tiene este proceso, resultado de una aspiración estilística y técnica tras un primer movimiento de irreflexiva espontaneidad. Las influencias de antes se han ido cristalizando con el seguro manejo de las palabras, y si alguna vez creemos reconocer a uno $\mathfrak{u}$ otro poeta tras los claros versos, no podemos dejar de sentir la unidad absoluta del poema. Algunos son muy hermosos; tales: "Y la nostalgia", "Agosto", "El primer adiós", "Palabras con tu nombre" que reflejan conflictos intimos, impulsos indefinibles y la paradoja de sentimientos hondos.

En la poesía de María Dhialma Tiberti predomina el elemento plástico y el movimiento de las imágenes regidas por el verbo antes que por el adjetivo, siempre parco:

La nostalgia tiene el talle fino $\mathrm{y}$ las manos azules, cuando se está solo sin soledad oyendo rumores imprecisos que nacen en la distancia y buscan su sitio en el mapa de sombras. ${ }^{11}$

Cabria preguntarse si los versos de esta joven son resultado solamente de la intuición de la juventud y por ello no tienen porve- 
nir, o si la autora posee además un auténtico don poético. Queremos creer esto último. En todo caso, ya nos ha dado algunas piezas antológicas que la consagran ante quienes sienten la poesía.

\section{Helena Percas, Grinnell College.}

\section{$\mathrm{NOTAS}$}

1 Portada de Cielo recto, La Plata, Castalia, 1947.

2 Así dice en "Copla":

La luna se hizo con ritmos.

Los ritmos se hicieron con agua.

El agua nació una noche

en que las estrellas lloraban. (pág. 50)

Compárese con:

La plaza tiene una torre,

la torre tiene un balcón,

el balcón tiene una dama,

la dama una blanca flor.

Antonio Machado.

3 Este libro dedicado "A la hermana agua" tiene todo él una simplicidad que nos recuerda a Nervo, aparte ya de algún elemento determinado como la repetición de versos al final de cada estrofa; a veces con una ligera variante más característica de Juan Ramón Jiménez. La expresión de angustias desconocidas nos recuerda a Pablo Neruda:

$Y$ en el estanque de agua oscura,

de ondas sin sonido,

culebrean desesperanzas

$y$ afloran temores informes;

la superficie es quieta, con quictud de espalda muerta. (Pág. 48)

Algunas palabras como "desesperanzas" y "temores informes" nos hacen pensar en la prosa de Azorín.

Algunas poesías recrean la atmósfera de la última etapa poética de Alfonsina Storni, como "Romántica", (pág. 66) que nos recuerda "Camp fire" de Mundo de siete pozos, o como "Noche inmusical" en que leemos:

E1 cielo es un pentagrama;

la estrella más luminosa

pinta una clave de $f a$ en el firmamento,

y las otras más pequeñas son notas... (pág. 26)

versos casi idénticos por la idea y la metáfora a los de "Página musical". de Mascarilla y trébol. 
368.

Otras poesías parecen haberse inspirado en Jorge Luis Borges, o por lo menos en su escuela. Véanse los siguientes versos de símiles típicamente borgianos:

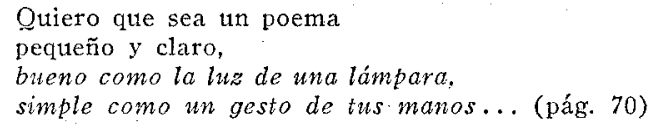

4 Juicio salido en Atlántida en enero de 1948 y obtenido por la amabilidad de la señorita Josefina Passadori.

5 Págs. 32, 38, 53, 54 y 70, respectivamente.

6 "Presentación y elogio de María Dhialma Tiberti", Alfar, Montevideo, 1949, núm. 88, año xxvir, s. p.

7 La Plata, ediciones del Bosque, 1948, p. 57.

8 El Día, abril 18, 1949.

9 Mayo de 1949. Juicio remitido por Josefina Passadori.

10 El Mundo, mayo 2, 1949.

11 La Plata, ediciones del Bosque, 1950, pp. 22-23. 